\title{
Analysis of Poverty Profile by Type of House of Households in Nepal
}

\begin{abstract}
Krishna Prasad Acharya*
\section{Abstract}

This study focuses on the Poverty Profile by type of house of Households in Nepal among 5,988 households of Nepal. It is based on the Nepal Living Standards Survey-III 2010/11 cross-sectional data. The data were used to analyze descriptive statistics including poverty profiles. The FGT poverty index (index proposed by Foster, Greer and Thorbecke) is employed to examine the head count rate or poverty incidence, poverty gap and severity poverty of Nepal. It reveals that $25.2 \%$ of the sample households live below the poverty line (Rs.19261 per individual per year) with an average poverty gap and squared poverty gap of $5.43 \%$ and $1.81 \%$ respectively. Households living in Pakki and Non-Pakki houses are 0.8 and 52.4 percent average poor and 0.2 and 1.7 percent core poor respectively.
\end{abstract}

Key words: poverty incidence, poverty gap, severity poverty

\section{Introduction}

Poverty is not new phenomenon. It has its affiliation with human since the beginning of human civilization. It does not have any watertight definition to define on the basis of economic status of a person. A poor person is one who does not have command over or access to the basic physical needs like adequate food, drinking water clothing and shelter and social needs like education and health (Joshi, 1997). However it is traditional approach to define poverty. Despite of these adequate too, a person can be poor due to relative factors of the society in which a person lives.

Poverty is visualized as "The State or Condition of having little or no money, goods, or means of support or to a condition of being in want of something that is needed, desired or generally recognized as having value". The meaning of poverty, therefore, not only varies from Society to Society but it also varies within the same Society at different points of time (Joshi, 1997).

Traditionally, poverty had been thought of in terms of relative deprivation. However, it sounds differently depending upon its content. Poverty exists in all countries and in all Societies and has various aspects viz, lack of income, productive resources, hunger and malnutrition, illiteracy, homelessness and inadequate housing, unsafe environment, social discrimination and exclusion (Joshi, 1997).

* Mr. Acharya is Associate Professor at Tribhuvan University, Faculty of Management, Shanker Dev Campus Email: acharyakrishna20@gmail.com 
In a developing country like Nepal, the problems of assessing the incidence of poverty are enormous, primarily because poverty is a multidimensional concept and the extent of poverty differs from one part of the country to the other. No single symptom of poverty can be relied upon for getting a realistic idea of the true incidence of poverty.

Household Survey of Central Bureau of Statistics (CBS) NLSS-III entitled as 'Household Survey' observed the configuration of 5,988 sample houses. Questioners, based upon the scale, foundation, style, occupation of rooms, toilet facility, pure drinking water and electricity, were exploited during the survey. Houses were dissected Pakki house and Non-Pakki house on the basis of the materials used for construction. Houses configured with the help of cemented wall, concrete pillars, concrete/cement or galvanized iron or tiles/slate roof attaching stones or bricks with the help of cement were labeled as Pakki house. Rests of the houses, erected with other materials were categorized as Non-Pakki house. Through the sample study of 5,988 houses and their nature of configuration, the surveyor tends to sketch the poverty profile of those householders. Therefore, this study intends to assess the poverty levels of the poor by type of houses.

\section{Method of data collection:}

This study is exclusively based on secondary data i.e., Nepal living standard survey2011(NLSS-III), Central Bureau of Statistics (CBS), Nepal.

\section{Method of Data Analysis:}

Frequency tables and percentages were used to describe the type of house of the households. The poverty profile of the households has been examined using standard measures of poverty such as the headcount ratio, poverty gap index and the squared poverty gap or FosterGreer-Thorbecke (FGT) Index. They are widely used because are consistent and additively decomposable (Foster et al., 1984). The FGT index is givền by

$$
P \propto \frac{1}{\mathrm{~V}} \sum_{\mathrm{i}=1}^{\alpha}\left(\frac{\mathrm{z}-\mathrm{y}_{\mathrm{i}}}{\mathrm{z}}\right)
$$

Where, $\mathrm{z}$ is official poverty line, $\mathrm{y}_{\mathrm{i}}$ is the household per capita consumption / expenditure of the $\mathrm{i}^{\text {th }}$ household, $\mathrm{q}$ is the number of poor people in the sampled population of size $\mathrm{N}$, and $\propto$ is the FGT parameter. The measures are defined for $\propto \geq 0$, where $\propto$ is measure of the sensitivity of the index to poverty. When $\propto=0$, we have the headcount index $P_{0}$ which measures the incidence of poverty, similarly for $\approx 1$ is the poverty gap indexp $p_{1}$, which measures depth of poverty for $\alpha=2$, it is the squared poverty gap index $P_{2}$ measuring the severity of poverty. According to the NLSS report 2010-11, the poverty line (z) was Rs 192611-individual per year (CBS Report, 2011). This poverty line is used in our study. 


\section{Results and discussion:}

\section{Types of house of Sample households:}

The outside wall of the houses which were made by cement bonded bricks/ stones are $32.48 \%$, the mud bonded bricks / stones are $46.03 \%$ and the bamboo / leaves are $13.31 \%$. The outside wall of the houses which were made by other materials was negligible (Table 1).

Table 1: Distribution of households by main construction material of outside wall:

\begin{tabular}{|l|c|c|}
\hline Construction material & No. of house frequency & Percent \\
\hline Cement bonded bricks & 1945 & 32.48 \\
\hline Mud bonded bricks/stones & 2756 & 46.03 \\
\hline Wood & 329 & 5.49 \\
\hline Bamboo/Leaves & 797 & 13.31 \\
\hline Unbaked bricks & 31 & 0.52 \\
\hline Other material & 129 & 2.15 \\
\hline No outside wall & 1 & 0.02 \\
\hline Total & 5,988 & 100.00 \\
\hline
\end{tabular}

The foundation of dwelling of houses which were made by pillar bonded is $17.23 \%$, cement bonded is $15.76 \%$, mud banded is $46.66 \%$ which is same as the outside wall of the houses which was made by the mud bonded bricks / stones and wooden pillar is $17.50 \%$. The foundation of dwelling of houses which were made by pillar bonded, cement bonded and wooden pillar are approximately same (Table 2).

Table 2. Distribution households by foundation of dwelling:

\begin{tabular}{|l|c|c|}
\hline Foundation Dwelling & Frequency (No of House) & Percent \\
\hline Pillar Bonded & 1032 & 17.23 \\
\hline Cement Bonded & 944 & 15.76 \\
\hline Mud Bonded & 2794 & 46.66 \\
\hline Wooden Pillar & 1048 & 17.50 \\
\hline Other & 170 & 2.84 \\
\hline Total & 5,988 & 100.00 \\
\hline
\end{tabular}

The roof of houses which are made by the main material of galvanized iron is $28.21 \%$, concrete cement $27.24 \%$ and the tiles/slate is $25.6 \%$ which are approximately same. The roof of houses which are made by the main material of straw/thatch is $15.90 \%$ while made by the other materials is negligible (Table 3).

Table 3: Distribution of households of roof made by main material:

\begin{tabular}{|l|l|l|}
\hline Roof & Frequency (No of House) & Percent \\
\hline Straw/Thatch & 952 & 15.90 \\
\hline Earth/Mud & 91 & 1.52 \\
\hline Galvanized Iron & 1689 & 28.21 \\
\hline Concrete/Cement & 1631 & 27.24 \\
\hline Tiles/Slate & 1537 & 25.67 \\
\hline Other & 25 & 0.42 \\
\hline Total & 5,988 & 100 \\
\hline
\end{tabular}


The Pakkihouses out of 5,988 households are $22.83 \%$ and the Non-Pakki houses are $77.17 \%$. It was seen from the (Table 4) that majority of the households lived in Non-Pakki houses.

Table 4: Distribution of households by Pakki and Non-Pakki house:

\begin{tabular}{|l|l|l|}
\hline Types of House & Frequency (No of House) & Percent \\
\hline Pakki & 1367 & 22.83 \\
\hline Non-Pakki & 4621 & 77.17 \\
\hline Total & 5,988 & 100 \\
\hline
\end{tabular}

The results from the FGT model showed that poverty incidence ofpakki houses to be 0.049 , poverty gap to be 0.008 and poverty severity to be 0.002 . This implies that $4.9 \%$ of the households are poor who lived in pakki houses, the averagely poor have $0.08 \%$ of the pakki houses and the severity of poverty are $0.02 \%$. Similarly $24.45 \%$ of the Non pakki households are poor, the averagely poor have $52.42 \%$ and the severity of the poverty are $1.75 \%$ (Table $5)$.

Table 5: Poverty Status in terms of Incidence, Gap and Severity:

\begin{tabular}{|l|c|c|c|}
\hline \multirow{2}{*}{ Types of house } & \multicolumn{3}{|c|}{ Poverty Profiles } \\
\cline { 2 - 4 } & $P_{0}$ & $P_{1}$ & $P_{2}$ \\
\hline Pakki & 0.049 & 0.008 & 0.002 \\
\hline Non-Pakki & 0.244 & 0.524 & 0.017 \\
\hline Nepal & 0.251 & 0.054 & 0.018 \\
\hline
\end{tabular}

\section{Summary and Conclusion:}

On the basis of our results we can conclude that poverty in the study area is 24.45 percent of households are Non-Pakkihouses. According to outside wall and foundation of dwelling, Pakki houses (cement bonded bricks/stone and pillar bonded) are 33 percent, where as Non-Pakki houses (mud bonded and others) are 46 percent .The poverty rate of Pakki House dwellers is 5 percent and Non-Pakki house dwellers is 24.45 percent, which is less than the total poverty rate of Nepal. Households living in Pakki and Non-Pakki houses are 0.8 and 52.4 percent average poor and 0.2 and 1.7 percent core poor respectively.

\section{References:}

CBS (2011), Nepal Living Standard Survey Report, Central Bureau of Statistics, Kathmandu, Nepal.

Joshi P. D. (1997), Conceptualisation, Measurement and Dimensional Aspects of Poverty in India, Paper presentation at Seminar on Poverty Statistics, Santiago.

Foster J., Greer J., and Thorbecke E. (1984), "A Class of Decomposable Poverty Measures", Econometrica, Vol.4 52(1). 